\title{
Experimental study detection of CD4+ and CD8+ T Cells in the brown adipose tissue
}

\author{
NYAMDORJ Dagdanbazar ${ }^{1}$, DAGDANBAZAR Bodi ${ }^{1}$, UURTUYA Shuumarjav ${ }^{2,3,}$, , \\ AMGALANBAATAR Dorjkhuu ${ }^{1}$, MUNKHTULGA Lkhagvasuren ${ }^{4}$, ENEBISH Sundui ${ }^{1}$ \\ ${ }^{1}$ Department of Anatomy, School of Bio-Medicine, Health Sciences University of Mongolia \\ ${ }^{2}$ Department of Physiology \& Pathophysiology, School of Bio-Medicine, Health Sciences University of Mongolia \\ ${ }^{3}$ Department of Clinical Laboratory Medicine, Jichi Medical University, Japan \\ ${ }^{4}$ School of Health Technology of Mongolia, Health Sciences University of Mongolia
}

\author{
Email address: \\ uurtuya@hsum-ac.mn (UURTUYA S.)
}

\section{To cite this article:}

NYAMDORJ Dagdanbazar, DAGDANBAZAR Bodi, UURTUYA Shuumarjav, AMGALANBAATAR Dorjkhuu, ENEBISH Sundui, MUNKHTULGA Lkhagvasuren. Experimental Study Detection of CD4+ and CD8+ T Cells in the Brown Adipose Tissue. American Journal of Clinical and Experimental Medicine. Vol. 2, No. 1, 2014, pp. 4-8. doi: 10.11648/j.ajcem.20140201.12

\begin{abstract}
Brown adipose tissues (BAT) have special active functions including thermogenesis, anti-obesity, and antidiabetic properties. Researchers have shown the immune roles of BAT in relation immune depression in deep hypothermia and lymphocyte accumulation in the spleen as detected in adipectomized rats. In this study we aimed to clarify immune functions of hibernating marmot BAT which continue to be used in pancreatitis treatment in Mongolia. In this study, 10 marmots were selected. The subject pool was limited license are needed for marmot use. Disengaged BAT was located between subcapularis and serratus anterior muscles. It was inserted into $96 \%$ of alcohol and $10 \%$ formalin for fixation. Histology examination was used with standard protocol of hematoxylin and eosin staining protocol. Fluorescenceactivated cell sorting method (Apogee Universal-50, England) was used to count the CD4+ and CD8+ T cells in the BAT of mice. The study selected BALB/c mode, 20 male mice 80-90 days-old. Marmots are not experimental animals therefore reagents of tissue cell count were limited. The BAT (marmot) histology observation showed connective tissue in the lobules reached by blood vessel branches and detected brown fat tissue surrounding follicle which included vessels with blood cells Regarding tissue cell count results, the BAT detected a total of $24827 / \mu \mathrm{L}$ lymphocytes, which included $2056 / \mu \mathrm{L}(5.50 \%)$ CD4+ T cells and $991 / \mu \mathrm{L}(6.71 \%) \mathrm{CD} 8+\mathrm{T}$ cells, respectively. This study's results suggest the brown fat is may be an immune organ as shown by the lymphoid tissue follicle and lymphocyte subsets in the BAT.
\end{abstract}

Keywords: Brown Adipose Tissue, Immune Cell, CD4+, CD8+

\section{Introduction}

Study on brown adipose tissue (BAT) structure and function started in1551 worldwide [1]. Morphologically, BAT cells are composed of typical adipocytes with multilocular distribution of fat, which are smaller than white adipose tissue. Functionally, the results of last year study have shown that BAT is an active endocrine tissue which enrolled thermogeneisis and lipid metabolism [2-4].

The importance of BAT for the maintenance of body temperature in hibernators and suppression of immune reactions by deep hypothermia suggest a relationship between BAT and immunity [3]. A few studies in this area have indicated that extracts obtained from hibernators' BAT are capable of suppressing the production of antibody in- vitro. However, the studies have demonstrated both in vivo and in non-hibernators the immunosuppressive activity of BAT; it was found that injections of extracts, prepared from rat $\mathrm{BAT}$, produced a considerable reduction of immune response. Furthermore, removal of BAT from newborn rats enhanced to a great extent the reactions of cell-mediated immunity [5-7].

BAT is more active in hibernators than non hibernator. Many researchers have demonstrated the immune function however there are no studies that detect immune cells in BAT so far. In this study we selected marmot BAT. The marmot is a hibernator and one of the most important medications used in pancreatitis in Mongolia. Therefore, it is necessary to clarify the unique structure of BAT to understand the key roles of marmot BAT. 


\section{Materials and Methods}

Our study was performed at the Laboratory of Research Training Center, School of Health Technology and Health Sciences University of Mongolia. The study 10 marmots selected. The subject pool was limited license are needed for marmot use. Disengaged BAT was located between subcapularis and serratus anterior muscles. It was inserted into $96 \%$ of alcohol and $10 \%$ formalin for fixation. Histology examination was used with standard protocol of Hematoxylin and Eosin (H\&E) staining [8]. The histological preparation of marmot and mice BAT was kept at $-20^{\circ} \mathrm{C}$. Light microscope examination with "Olympus", gain $40 \times 10$.

The histological examination used the tissue lymphocyte cell count method, since the marmot tissue lymphocyte reactivity was limited. For this reason, the study selected a BALB/c mode, 20 male mice with 80-90 days-old to confirm the histological results. Disengaged interscapular brown fat was located in the external thoracic region of mice. Fluorescence-activated cell sorting (FACS) provides a rapid means of isolating large numbers of fluorescently tagged cells from a heterogeneous mixture of cells. FACS (Apogee Universal-50, England) was used to count the lymphocyte subsets CD4+ and CD8+ count in the mice BAT. The lymphocyte subsets in the 2 tubes (Sample 1 and Sample 2), were futher divided into 2 tubes (Sample 1-1/Sample 1-2 and Sample 2-1/Sample 2-2). The CD4+ T cells were counted in the Sample 1-1 and Sample 1-2. The CD8+ T cells were counted in the Sample 1-2 and Sample $2-2$, respectively. In the study, the mean value of lymphocyte subsets was used.

\section{Results}

The marmot BAT macrostructure is rhombus or square with a rose-pink color, an average size of $4.3 \times 2.7 \mathrm{~cm}$, an average weight of $3.5 \mathrm{~g}$, and a surrounding capsule (Figure 1). The histology observation of BAT showed high vascularization in horizontal and cross section of connective septum between lobules (Figure 2). Interestingly, in this study, we found lymphoid tissue accumulation (follicle) (Figure 3) and Hassall's corpuscle in the marmot BAT (Figure 4). The lymphatic follicles were rich with vessels with blood cells.

Regarding tissue lymphocyte count results, mice BAT detected $\mathrm{CD} 4+$ and $\mathrm{CD} 8+\mathrm{T}$ cells using standard reagents with FACS. According to histogram results, in the first sample of BAT, a total of $6313 / \mu \mathrm{L}$ lymphocytes were detected in the 1-1 tube, and $1347 / \mu \mathrm{L}$ lymphocytes in the 12 tube, respectively. The ratio of $\mathrm{CD} 4+$ and $\mathrm{CD} 8+\mathrm{T}$ cells were $369 / \mu \mathrm{L}(5.68 \%)$ vs. $113 / \mu \mathrm{L}(5.88 \%)$, respectively (Figure 5, Table 1). In the second sample, a total of $60551 / \mu \mathrm{L}$ lymphocytes were detected in the 2-1 tube with BAT and $31095 / \mu \mathrm{L}$ lymphocytes in the 2-2 tube with BAT, respectively. The ratio of $\mathrm{CD} 4+$ and $\mathrm{CD} 8+\mathrm{T}$ cells were $3746 / \mu \mathrm{L}(5.20 \%)$ vs. $1868 / \mu \mathrm{L}$ (4.99\%) (Figure 6, Table 1).
In the BAT a total of $24827 / \mu \mathrm{L}$ lymphocytes, which included $2056 / \mu \mathrm{L}(5.50 \%)$ lymphocytes CD4+ T cells and 991/ $\mu \mathrm{L}$ (6.71\%) lymphocytes CD8+ T cell, respectively (Table 1).

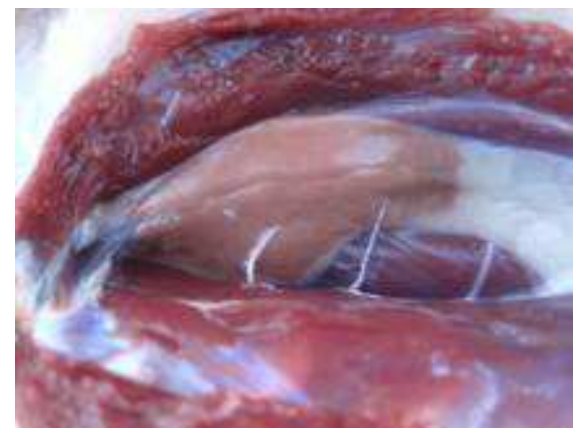

Figure1. Brown fat of marmot. The black arrow showed brown fat located between subcapularis and serratus anterior muscles.

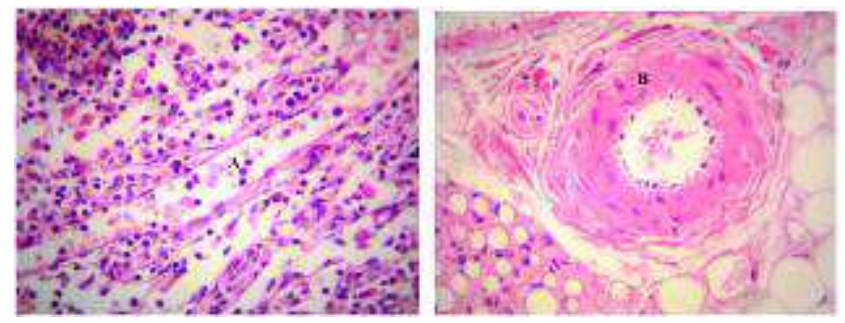

Figure 2. Histology preparation of marmot brown adipose tissue (x400). Staining H\&E. A. Horizontal section of vessel (venule) in the BAT with white cells. B. Cross section of vessel (arteriole) with blood cells in the $B A T$.

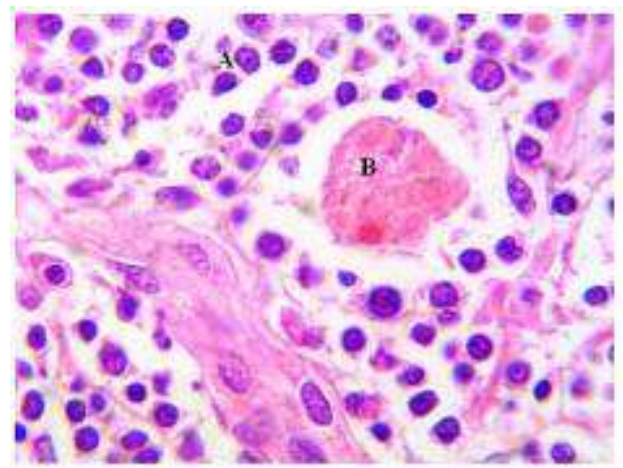

Figure 3. Histology preparation of marmot brown adipose tissue (x1000). $H \& E$ staining. A. The lymphatic follicles, $B$. Hassell's corpuscle.

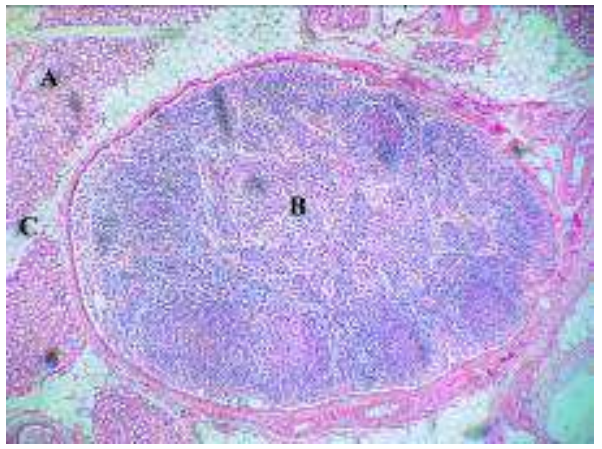

Figure 4. Histology preparation of brown adipose tissue (x40) microstructure of marmot. $H \& E$ staining. A. Brown adipose tissue. B. Lymphoid tissue C. Connective septum between lobules 

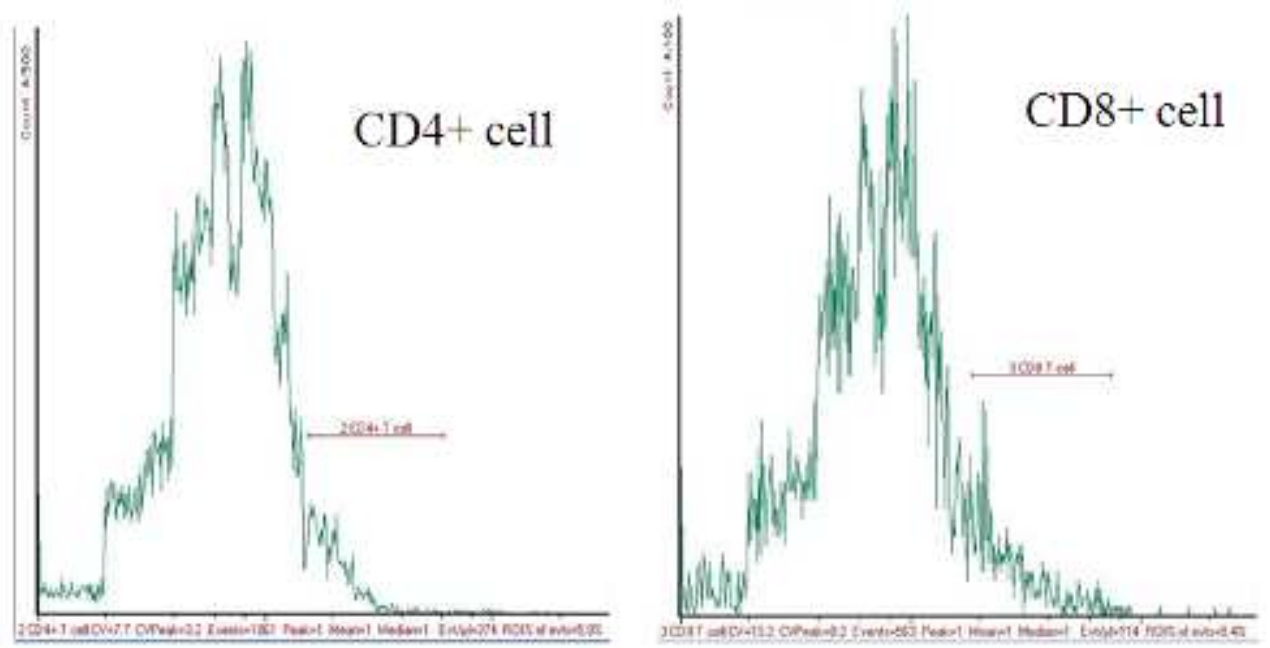

Figure 5. $C D 4+T$ and $C D 8+T$ cells in the BAT of mice

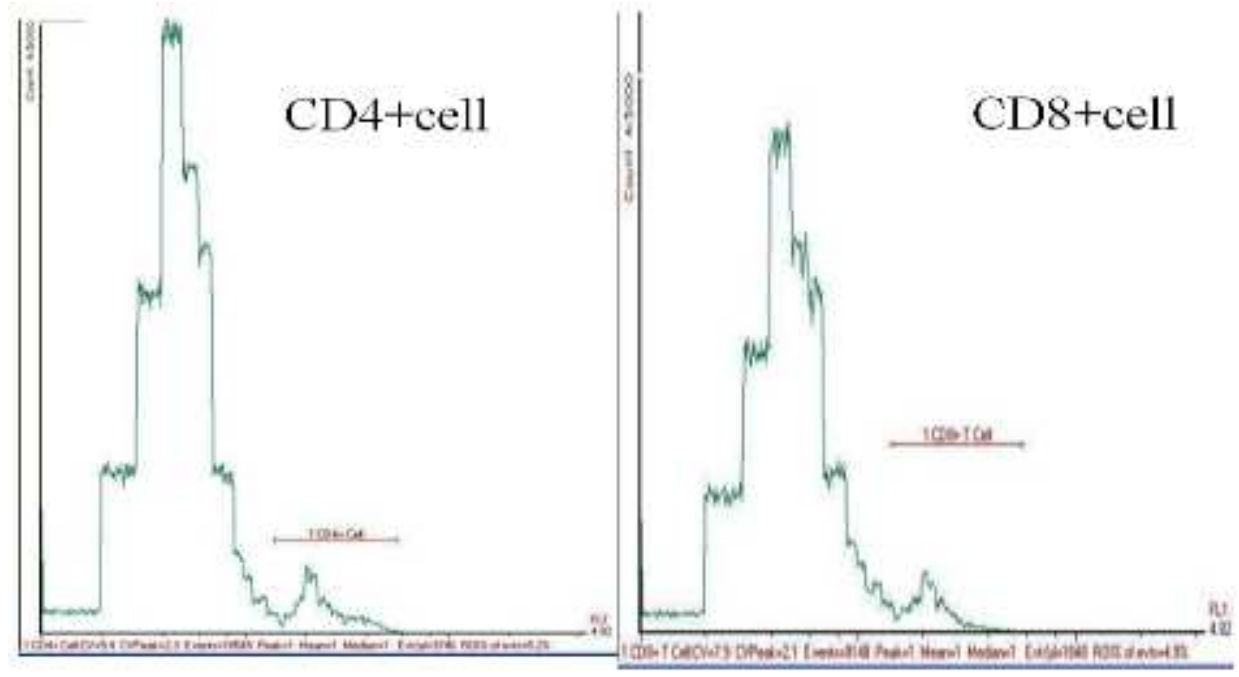

Figure 6. $C D 4+T$ and $C D 8+T$ cells in the BAT of mice

Table1. Incidences of lymphocytes and CD4+, CD8+ subsets in the BAT of mice

\begin{tabular}{llllllll}
\hline & BAT & \multicolumn{2}{c}{ Cells connected to CD4+ antibody } & \multicolumn{3}{c}{ Cells connected to CD8+ antibody } \\
Samples & $\begin{array}{l}\text { Lymphocytes } \\
(1 / \mu \mathrm{L})\end{array}$ & Lympho-cytes & $\begin{array}{l}\text { Lympho-cytes } \\
(1 / \mu \mathrm{L})\end{array}$ & $\begin{array}{l}\text { Percentage } \\
\text { in the cell }(\%)\end{array}$ & $\begin{array}{l}\text { Lympho- } \\
\text { cytes }\end{array}$ & $\begin{array}{l}\text { Lymphocytes } \\
(1 / \mu \mathrm{L})\end{array}$ & $\begin{array}{l}\text { Percentage } \\
\text { in the cell }(\%)\end{array}$ \\
\hline $\begin{array}{l}\text { Sample 1-1 } \\
\text { Sample 1-2 }\end{array}$ & 6313 & 1839 & 369 & 5.85 & 562 & 113 & 8.43 \\
Sample 2-1 & 1347 & 60551 & 18545 & 3742 & 5.20 & & \\
Sample 2-2 & 31095 & & & & 9251 & 1868 & 4.99 \\
Mean value & 24827 & 10192 & 2056 & 5.50 & 4907 & 991 & 6.71 \\
\hline
\end{tabular}

BAT; brown adipose tissue, $\mathrm{CD}$; cluster of differentiation, $\mu \mathrm{L}$; micro liter;

\section{Discussion}

Current data from animal studies indicate that a reduced amount or function of BAT leads to obesity, insulin resistance, and dyslipidemia [9-12]. Our study aim was to clarify marmot BAT structure for determining immune key roles. The marmot brown fat is highly vascular, usually characterized by multilocular lipid droplets and smaller, compared to white fat which is a complex endocrine system [13]. The marmot BAT macrostructure of the rhombus or square shape and color is rose-pink similar to the structure of the Persian lamb, newborn mouse, rat, and human BAT, 
however, the average size and weight are different $[14,15]$. The highlight findings of the study are a lymphoid tissue accumulation (follicles) and Hassall's corpuscle detection in the marmot BAT by histology examination. Unfortunately, we did not find any comparative study to compare our study results with. The Hassall's corpuscle (thymus corpuscles-bodies) is structures found in the medulla of the thymus. Embryologically, the thymus is derived from all 3 germinal layers and arises primarily from the third pharyngeal pouch [16]. The primordium fuse in the midline and the thymus then descends into its usual anatomical position in the anterior mediastinum, where there is a regression of the endoderm and lymphocyte invasion to form the characteristic Hassall's corpuscle. Hassall's corpuscle is active in many antigen expression, cell signaling, transcription, and metabolism mediated by cytokines or growth factor receptors [17-19]. Watanabe et al. [20] revealed that Hassall's corpuscles have a critical role in dendritic-cell-mediated secondary positive selection of medium-to-high affinity self-reactive $\mathrm{T}$ cells, leading to the generation of $\mathrm{CD} 4+\mathrm{CD} 25+$ regulatory $\mathrm{T}$ cells within the thymus [21]. Some researchers'study results explain that thymus and brown fat have immune inverse function. The discrepancy between the humoral and cell-mediated immune response in adipectomized rats, the neonatal excision of the inter-scapular BAT represents, in fact, an incomplete adipectomy, which leaves intact other deposits of BAT, so that the amount of tissue in adipectomized rats is sufficient enough to allow a normal production of antibodies. Reasoning of this kind would imply that in non-hibernators the mechanisms which under-lie cellmediated immunity are more sensitive to the lack of BAT than the mechanisms primarily involved in humoral immunity [3]. The lymphoid follicles in the marmot BAT were also detected in the hamster BAT of the histology examination research study result [22]. The difference was the marmot BAT's development of the vessel smooth muscle layer was higher than the hamster's [22-24]. In this study, we would like to demonstrate our study results, so we conducted the study on mice as well since they are part of the same rodent group. The CD4+ and CD8+ $\mathrm{T}$ cell count is demonstrated in our histological results. Khongorzul B. et al study showed the percentage of CD4 $+\mathrm{T}$ and CD8 $+\mathrm{T}$ cell in the peripheral vascular blood of mice [25]. The lymphocyte subsets in the BAT may be related to the function of Hassall's corpuscle which was found in our study. There are not enough studies to compare the generation of lymphocytes in the BAT. This study is subject (marmot) numbers were limited because of hunting regulations. This research study is the first study aimed detecting and demonstrating immune cells in the marmot BAT. Therefore immune cells were also counted in the BAT of mice.

\section{Conclusions}

The results indicate that the lymphoid tissue follicles and lymphocyte subsets in the BAT including CD4+ and CD8+ T cells may be related to the function of Hassall's corpuscle. The Hassall's corpuscle in the BAT is a unique structure of marmot BAT. On the other hand, our study suggests BAT may be an immune organ like the thymus. Future studies are necessary to clarify unique immune roles of marmot BAT.

\section{References}

[1] Gessner K. History of Animals, "Conradi Gesneri medici Tiguine Historiae Animalium Lib I de Quadripedibus uiuparis" Book 1 of Four-Legged Uniparous 1551, pp.840844.

[2] Carlos jinqueira L, "Basis histology" 1996, pp. 129-131.

[3] Orava J, Nuutila P, Oikonen V, Noponen T, Virtanen KA, "Human brown adipose tissue glucose uptake but not perfusion is stimulated by insulin" [ICO 2010 congress abstract]. Obesity

[4] B.D. Jankovic, AlenkaJanezic and Ljiljana Popeskovic, "Brown adipose tissue and immunity. Effect of neonatal adipectomy on humoral and cellular immune reactions in the rat" Immunology 1975, 28:597-609.

[5] Petric. J, "Contribution a la serologie des mammiferes" Publ.Fac.Med.Brno R.C.S 1992, 1, 247.

[6] Schmidt. J. P, "Response of hibernating animals to physical, parasites and infectious agents" Mammalian Hibernation volume 3 (By K. C. fisher, A.R. Dawe, C.P.Lyman, E.Schonbaum and F.E.South, Jr), 1967, pp. 421. Oliver \& Boyd, Edinburgh

[7] Jancovic, B. D., Popeskovic, L., Janezic, A. and Lukic, M.L, "Brown adipose tissue: effect on immune reactions in the rat" Naturwissenschaften, 1974; pp.61,36.

[8] Educational guide, Special Stains and H\&E, Second Edition. George L.Kumar, John A. Kierman 2010.

[9] Feldmanm HM, Golozoubova V, Cannon B, Nedergaard J, "UCP1 ablation induces obesity and abolishes diet-indused thermogenesis in mice exempt from thermal stress by living at thermoneutrality" Cell Metab 2009; 9:203-209.

[10] Cannon B, Nedergaard J, "Thermogenesis challenges the adipostat hypothesis for body-weight control" Proc Nutr Soc 2009; 68:401-407.

[11] Cederberg A, Gronning LM, Ahren B, Tasken K, Carlsson P, Enerback S, "FOXC2 is a winged helix gene that counteracts obesity, hypertriglyceridemia, and diet-induced insulin resistance" Cell 2001; 106:563-573.

[12] Hamann A, Flier JS, Lowell BB, "Decreased brown fat markedly enhances susceptibility to diet-induced obesity, diabetes, and hyperlipidemia" Endocrinology 1996; 137:2129

[13] Cannon B, Nedergaard J. Brown adipose tissue: function and physiological significance. Physiol Rev. 2004; 84:277359 .

[14] Г.Пүрэвдорж "Хүн ба зарим хөхтөн амьтны бор өөхний бүтэц, тосны хүчлийн агууламж, химийн бүрдлийн онцлогийг судлах асуудалд" докторын ажил 2005 он хуудас 55-60 
[15] Leonard Napolitano and Don Fawcett, "The fine structure of brown adipose tissue in the newborn mouse and rat" $\mathrm{J}$ Biophys Biochem Cytol. 1958; 25:685-692.

[16] Tovi F, Mares AJ, The aberrant cervical thymus: Embriology, pathology, and clinical implication. Am J Surgery, 1978; 136:631-637.

[17] Ushiyama I, Kouno A, Yamamoto Y, Nishimura A, Ito, et al, "Hassall's corpuscle fumction as the secretory cell groups" Forensic Pathology 1997; 3: 111-117.

[18] Romagnani P, Annunzaito R, Mavilia C, Lasagni L, et al, "High CD30 ligand expression by epithelial cells and Hassall's corpuscles in the medulla of human thymus ", Blood 1998; 91:3323-3332.

[19] Nishio H, Matsukui K, Tamura A, Suzuki K, Immunolocalization of the mitogen-activated protein kinase signaling pathway in Hassall's corpuscles of the human thymus. Acta Histomech 2001; 103: 89-98.

[20] Watanabe N, Wang YH, Lee HK, Ito T, Wang YH, et al, Hassall's Corpuscles instruct dendritic cells to induce
CD4+CD25+ regulatory $\mathrm{T}$ cells in human thymus. Nature 2005; 436:1181-1185.

[21] "Histochemical and morphological characteristics of the Hassall's corpuscles. The stress affects involution of the ectopic intra-thyroidal and the normal position thymus and morphological changes of the Hassall's corpuscles" J Forensic Res 2012; 3:9.

[22] Dagdanbazar B, Dugarsuren C, "Situation study of marmot "Khun makh" Presentation. Ulaanbaatar city,1990, pp.3640. (in Mongolian)

[23] Jancovic, B. D., Popeskovic, L., Janezic, A. and Lukic, M.L, "Brown adipose tissue: effect on immune reactions in the rat" Naturwissenschaften, 1974; pp.61,36.

[24] Dagdanbazar D, "Role of publication for development of modern anatomy of Mongolian doctors" Dissertation -UB; 2002, 126-133. (In Mongolian)

[25] Khongorzul B, "Some treatment effects in derived arthritis mouse model by roentgen analyses" dissertation of master science. UB 2013, pp. 59-60 (in Mongolian). 